\title{
The Approaches of Positive Experience Design on IOT I ntelligent Products
}

\author{
Chunmao $\mathrm{Wu}^{1}$, Huayuan $\mathrm{Xu}^{1}$ and Ziyang $\mathrm{Liu}^{{ }^{*}}$ \\ ${ }^{1}$ College of Fashion \& Design \\ Donghua University, Shanghai, P.R. China \\ [e-mail : cmwu@dhu.edu.cn, 13256044989@163.com] \\ ${ }^{2}$ Kyonggi University, Suwon-si, Gyeonggi-do, 16227, Republic of Korea \\ [e-mail : victor@kyonggi.ac.kr] \\ * Corresponding author: Ziyang Liu
}

Received February 19, 2021; revised April 4, 2021; accepted May 13, 2021; published May 31, 2021

\begin{abstract}
This paper proposes a positive experience design approach for Internet of Things (IoT) intelligent products to improve users' subjective well-being in the fields of artificial intelligence and big data. First, the authors selected six target users and taking the Xiaomi IoT intelligent products for the research objects and conducted a thorough observation on how the target users used IoT intelligent products in their own homes over two weeks via a homevisiting interview, group diary, and focus group. Second, they constructed an individual activities table for the participants' IoT intelligent product experience using a hierarchical task analysis (HTA). Third, two researchers sorted out the sub-tasks of happiness in the HTA table. Finally, the authors found the positive experience design approach of IoT intelligent products. The positive experience design approach of IoT intelligent products is proposed from focusing on the personal pleasure experience to individual life meaningful design and group social relationship design, including individual pleasure experience, personal goal realization, group needs satisfaction and the harmony of group relations. The paper uses the two design examples of an interactive kettle and a harmonious chair to further discuss the feasibility of the design approach. In the era of big data, it is helpful for designers to use this design approach to improve the users' sense of sustainable pleasure, achievement perception of their future goal realization, and the well-being of the group's social relationships.
\end{abstract}

Keywords: Positive Experience, IoT Product, Artificial Intelligent, Design Approach.

This research was supported by a research grant from Shanghai Pujiang Program (Grant No.19PJC003), National Social Science Fundation of China (Grant No. 17ZDA020). 


\section{Introduction}

O ver the last few years, the internet of things (IoT) has become more involved in people's daily lives, work, and studies. Through the use of products, networks, and sensors, powerful applications and services have been produced, and people's lifestyles have changed. However, there has been limited research on the design of IoT products in people's homes [1]. In the field of design and positive psychology, positive design is becoming a popular research direction. Positive design is a possibility-driven activity with positive value creation that provides pleasure and meaningful interactive experiences for individuals and communities via innovative products, services, and systems. This improves human well-being and communityflourishing, and contributes to an improved future [2, 3]. Research on how IoT product design can improve people's subjective well-being remains insufficient. The purpose of this paper is to build a positive experience design approach for IoT products that is conducive to the improvement of subjective well-being. This will help designers to do IoT product experience design practice more effectively under the guidance of the approach.

\section{Literature Review}

\section{1 loT Products}

The concept of IoT can be traced back to Bill Gates' book The Road Ahead, which was published in 1995. In 1999, Kevin Ashton, the co-founder of MIT's (Massachusetts Institute of Technology) automatic identification center, formally proposed the following concept of IoT: the information of all objects is connected to the internet through radio frequency identification (RFID) sensor devices for intelligent management and identification. In 2005, the International Telecommunication Union (ITU) pointed out that the ubiquitous "internet of things" communication era was coming and that all global goods, from tires to toothbrushes, houses and tissues, would be connected and able to interact [4]. In short, the internet of things is a new technology that is based on the internet. It combines goods with the internet to form a large network to realize the interconnection of people, machines and things at any time and place.

IoT products comprise sensor equipment, communication infrastructure, cloud computing, a processing unit, decision-making, and an action call system. These components and systems cooperate with each other through their own unique functions to realize the highly intelligent and automatic products. Users can improve their quality of life according to the information provided by the IoT products [5]. At present, IoT products have been widely used in various areas (as shown in Table 1). For example, in the automobile field, sensors have been installed to provide drivers and maintenance personnel with relevant potential risk information [6]. In the smart home field, air conditioners and purifiers can be remotely controlled through the internet to create a more convenient, safe, and comfortable home living environment [7]. In the medical field, intelligent wearable products have been adopted to allow individuals to wear the sensor in the device to sense the patient's physical condition and contact the hospital for a diagnosis when necessary [8]. 
Table 1. Related IoT works.

\begin{tabular}{|l|l|l|}
\hline Brand & Description of IoT works & $\begin{array}{l}\text { Industrial } \\
\text { category }\end{array}$ \\
\hline \hline Uber & $\begin{array}{l}\text { A digital travel IoT platform that integrates the service industry and } \\
\text { the internet of intelligent vehicles. }\end{array}$ & $\begin{array}{l}\text { Intelligent } \\
\text { travel }\end{array}$ \\
\hline TESLA & $\begin{array}{l}\text { Uses intelligent IoT technology to focus on the innovation of security; } \\
\text { rear, side, and forward-facing cameras provide maximum visibility; } \\
\text { the forward-facing radar provides a long-range view of distant objects; } \\
\text { detects nearby cars, prevents potential collisions and assists with } \\
\text { parking. }\end{array}$ & \\
\hline Thin Q (LG) & $\begin{array}{l}\text { A smart home that connects to the TV, Kitchen, laundry and other } \\
\text { appliances to provide an intelligent way of living. }\end{array}$ & $\begin{array}{l}\text { Smart } \\
\text { home }\end{array}$ \\
\hline Xiaomi & $\begin{array}{l}\text { Based on the future scenario of a smart home, it is an open innovation } \\
\text { platform that integrates artificial intelligence and IoT. }\end{array}$ & \\
\hline $\begin{array}{l}\text { U-home } \\
\text { (Haier) }\end{array}$ & $\begin{array}{l}\text { By combining wired and wireless networks, all devices are connected } \\
\text { to the network through information sensing devices to realize the IoT, } \\
\text { as well as intelligent identification, management, and digital media } \\
\text { information sharing through the IoT. }\end{array}$ & \\
\cline { 1 - 2 } Ali-Health & $\begin{array}{l}\text { Ali-Health mainly focuses on pharmaceutical e-commerce and new } \\
\text { retail, internet medical, consumer medical, smart medical, and other } \\
\text { fields. }\end{array}$ & $\begin{array}{l}\text { IoT } \\
\text { medical }\end{array}$ \\
\cline { 1 - 2 } $\begin{array}{l}\text { Health Suite } \\
\text { Digital } \\
\text { Platform } \\
\text { (PHILIPS) }\end{array}$ & $\begin{array}{l}\text { It is a service platform that integrates health, accurate diagnoses and } \\
\text { treatment, image intervention treatment and internet care. }\end{array}$ & \\
\hline
\end{tabular}

\subsection{Positive Experience Design}

Positive experience originates from positive psychology, which is a discipline that studies the optimal operating conditions and processes of people, groups, and institutions, and contributes to human flourishing [9]. Positive psychology focuses on what makes life valuable and what conditions determine human well-being. It studies the things that people think are meaningful in life, including the factors that make people happy, to solve the problems in human life [10]. Positive experience design is based on positive psychology; through the positive design of intervention behavior, interactions between people and products or services give people a positive experience. This experience is not only conducive to individual development but also to the flourishing of the environment or community. It is not only satisfied with short-term happiness, but also has a long-term positive impact on individual development [11].

The purpose of the positive experience design is to improve people's subjective wellbeing, which can be realized through the following three dimensions: short-term pleasure, long-term well-being, and the flourishing of the community (as shown in Table 2). From the perspective of short-term pleasure, Hassenzahl [12] proposed six basic psychological needs as the source of positive product experience. Additionally, Wu Chun-mao [13] put forward the concept design canvas based on the positive experience approach, which designers can use to capture users' positive design opportunities in a standardized and rapid manner. From the perspective of meaningful design, Orth [14] applied the product attachment theory to the design process of customized products and verified the importance of forming a meaningful association between objects and individuals through the design case study. Casais [15] stated that the symbolic meanings of products can promote happiness and put forward 16 design directions that can be used for conceptualization. Moreover, Wiese [16] pointed out that 
sustainable happiness depends more on user behavior than on material wealth, and Ozkaramanli [17] proposed three design strategies to improve subjective well-being driven by the self-control dilemma contradiction of short-term pleasure and long-term well-being. From the perspective of community flourishing, Maria [18] found that although self-focused happiness activities increased well-being, by showing increases over time, other-focused happiness activities consistently outperformed such increases. Jimenez introduced several design cases on community well-being. Based on the above literature research, this paper proposes a positive experience design approach of IoT products to improve subjective wellbeing through research into the user experience of IoT products.

Table 2. Literature on the positive experience design.

\begin{tabular}{|c|c|c|}
\hline Authors & Contributions & Classification \\
\hline $\begin{array}{l}\text { M. Hassenzahl } \\
\text { et al. (2013) } \\
{[12]}\end{array}$ & The six sources of positive experience & \multirow[t]{5}{*}{$\begin{array}{l}\text { Positive emotions } \\
\text { promote short- } \\
\text { term pleasure. }\end{array}$} \\
\hline $\begin{array}{l}\text { J. K. Yoon et al. } \\
\text { (2016) [19] }\end{array}$ & $\begin{array}{l}\text { The influence of positive emotion granularity on the user's } \\
\text { experience and happiness. }\end{array}$ & \\
\hline $\begin{array}{l}\text { P. M. A. Desmet } \\
\text { et al. (2019) } \\
\text { [20] }\end{array}$ & $\begin{array}{l}\text { Innovative design tools to stimulate user preferences, } \\
\text { emotions and emotional dynamics during the design } \\
\text { process. }\end{array}$ & \\
\hline $\begin{array}{l}\text { C. M. Wu et } \\
\text { al. (2020) [21] }\end{array}$ & A concept design canvas based on positive experience. & \\
\hline $\begin{array}{l}\text { P. M. A. Desmet } \\
\text { et al. (2020) } \\
\text { [22] }\end{array}$ & 13 fundamental psychological needs of pleasure. & \\
\hline $\begin{array}{l}\text { D. Orth et al. } \\
\text { (2018) [14] }\end{array}$ & $\begin{array}{l}\text { The attachment theory is applied to product design to form } \\
\text { a meaningful connection between the product and user to } \\
\text { enhance the subjective well-being. }\end{array}$ & \multirow[t]{4}{*}{$\begin{array}{l}\text { Positive meaning } \\
\text { improves long- } \\
\text { term well-being. }\end{array}$} \\
\hline $\begin{array}{l}\text { M. Casais et al. } \\
\text { (2018) [15] }\end{array}$ & $\begin{array}{l}\text { The symbolic meaning of products can promote people's } \\
\text { well-being. }\end{array}$ & \\
\hline $\begin{array}{l}\text { L. Wiese et al. } \\
\text { (2019) [16] }\end{array}$ & $\begin{array}{l}\text { Sustainable well-being depends more on user behavior than } \\
\text { material wealth. }\end{array}$ & \\
\hline $\begin{array}{l}\text { D. Ozkaramanli } \\
\text { et al. (2017) } \\
\text { [17] }\end{array}$ & Three design strategies to improve long-term well-being. & \\
\hline $\begin{array}{l}\text { S. Maria et al. } \\
\text { (2017) [18] }\end{array}$ & $\begin{array}{l}\text { Other-focused happiness activities can better contribute to } \\
\text { the long-term well-being. }\end{array}$ & \multirow{2}{*}{$\begin{array}{l}\text { Positive } \\
\text { interaction } \\
\text { contributes to the } \\
\text { flourishing of the } \\
\text { community. }\end{array}$} \\
\hline $\begin{array}{l}\text { S. Jimenez et al. } \\
\text { (2015) [23] }\end{array}$ & Design cases on the well-being of the community. & \\
\hline
\end{tabular}

\section{Research Method}

\subsection{Target Product}

In this study, Xiaomi IoT products were selected as the research objectives (Fig. 1) because they not only conform to the basic characteristics of IoT products [24] but also represent 
China's smart homes and have a wide-ranging user group. It is convenient for the authors to recruit target users and observe how the users perceive, experience, and interact with IoT products to investigate the motivation behind the interactions between users and IoT, and the interaction factors that affect users. This will contribute to future IoT product design practices.

The Xiaomi smart home system, which uses the Xiaoai speaker (name of a Xiaomi smart speaker) as the control center, uses AI technology to connect daily home products. Through the voice interaction with the Xiaoai speaker, the intelligent home products, such as lighting equipment, air conditioners, and air purifiers, can be controlled, and the control instructions can be customized according to the application scenarios. In addition, the Xiaomi smart home series includes a variety of sensors to achieve highly intelligent products. For example, air conditioning is controlled by the temperature and humidity sensors, light is controlled by the human body sensor, and the air purifier is controlled by the door and window sensors. After the initial setting of the above products, there is no need for user operation, as the products will coordinate with each other to meet the users' needs.
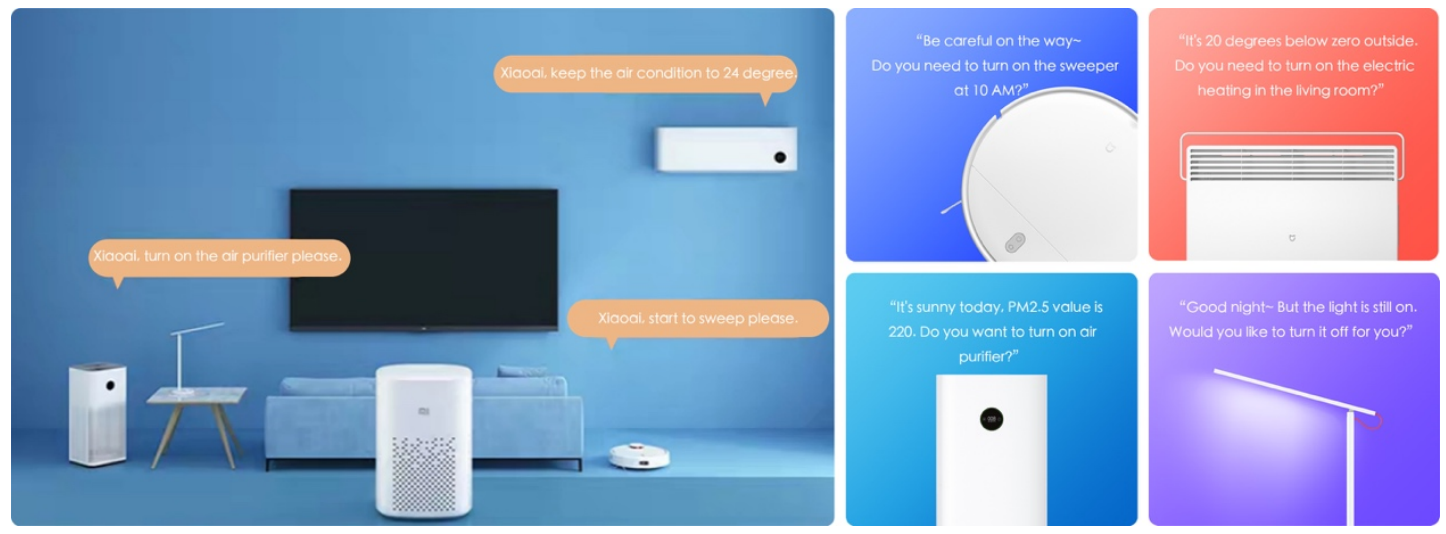

Fig. 1. Xiaomi IoT products.

\subsection{Participants}

This study recruited six participants from different families who used Xiaomi IoT products in the local community. These six participants were not expert users of IoT products. As shown in Table 3, the participants' ages, occupations, living conditions, and familiarity with IoT products were different. The participants were divided into the following two groups: group 1 (G1), who had a high familiarity with digital products; and group 2 (G2), who had a low familiarity with digital products [25]. The research process was conducted in the participants' homes via two weeks of in-depth observation. Meanwhile, the behavior and thoughts of the participants were recorded using videos and questionnaires.

Table 3. Participant profiles.

\begin{tabular}{|c|c|c|c|c|c|}
\hline & NO. & $\begin{array}{c}\text { Profile } \\
\text { (gender, age, occupation) }\end{array}$ & Lives with & $\begin{array}{c}\text { Knowledge of } \\
\text { the IoT }\end{array}$ & $\begin{array}{c}\text { Digital } \\
\text { familiarity }\end{array}$ \\
\hline \hline \multirow{3}{*}{ G1 } & P1 & Female,26, student & roommate & Heard of it & High \\
\cline { 2 - 6 } & P2 & Male,25, student & Parents & $\begin{array}{c}\text { Xiaomi } \\
\text { Products }\end{array}$ & High \\
\cline { 2 - 6 } & P3 & Female,35, office worker & $\begin{array}{c}\text { Husband, } \\
\text { Child and } \\
\text { parents }\end{array}$ & None & High \\
\hline
\end{tabular}




\begin{tabular}{|c|c|c|c|c|c|}
\hline & P4 & Female,26, office worker & Husband & $\begin{array}{c}\text { Parts of } \\
\text { Xiaomi } \\
\text { products }\end{array}$ & High \\
\hline G2 & P5 & Male,42, office worker & $\begin{array}{c}\text { Wife and 2 } \\
\text { kids }\end{array}$ & None & Low \\
\cline { 2 - 6 } & P6 & Female,45, housewife & $\begin{array}{c}\text { Husband and } \\
\text { Child }\end{array}$ & None & low \\
\hline
\end{tabular}

\subsection{User Research Methods}

To understand how the participants, perceived and experienced the IoT products, this study used the home interview, group diary, and focus group methods, as shown in Fig. 2.
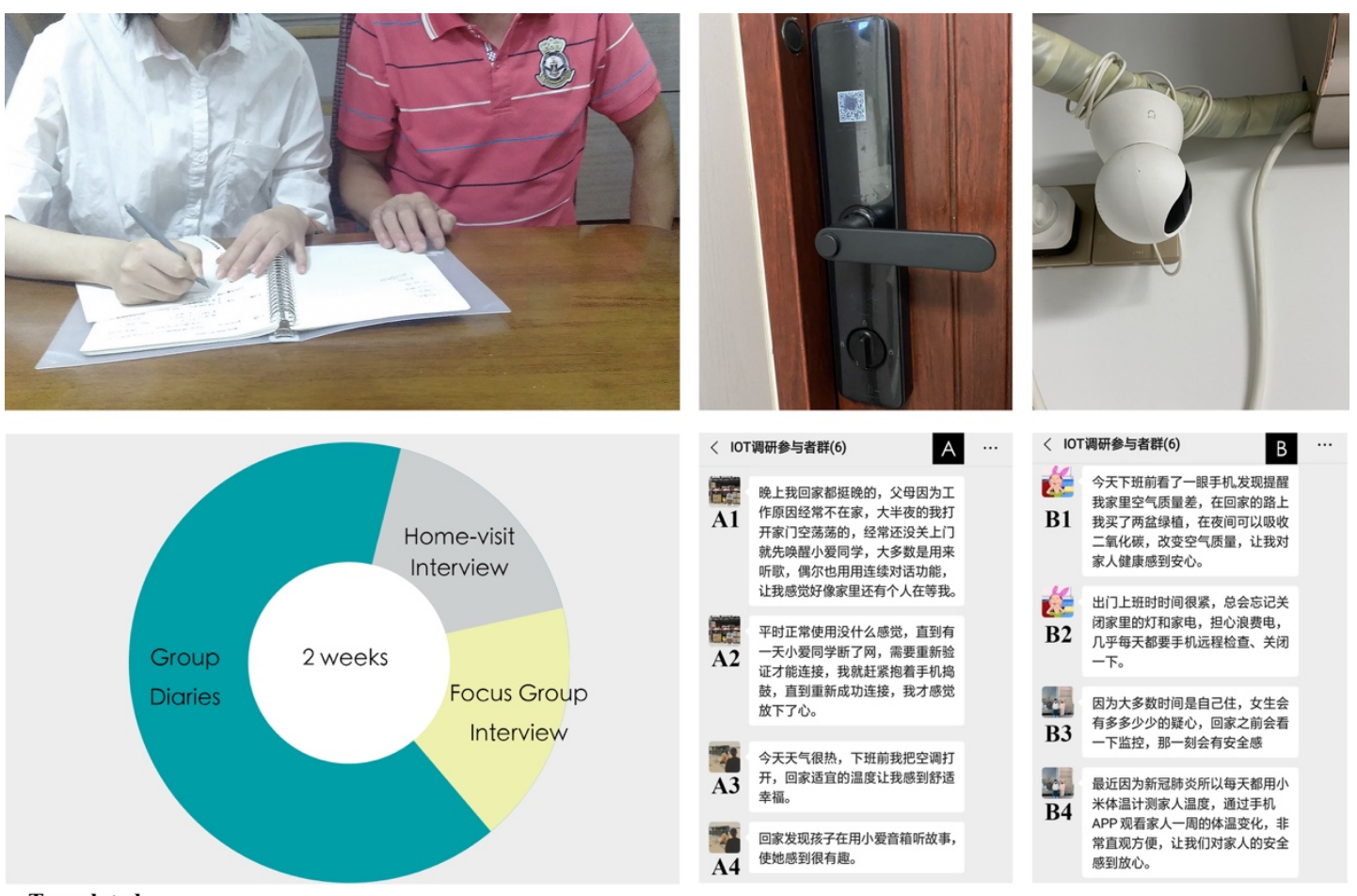

Translated:

A . 1. I go home late in the evening. Often, my parents are not back to home who have not finished their work. In the middle of the night, when I open the door, there is no one at home. I usually call Xiaoai before closing the door. Most of times I listen to music from Xiaoai, and occasionally I use the dialogue function, which brings me good emotions just like someone is waiting for me at home.

2. Usually I do not have special feelings on the value of Xiaoai, until one day Xiaoai disconnected to the web which need re-connect to recover its

function. I took the mobile phone to deal with the problem as quickly as I can. When the problem is solved and it connected to internet, I can take it easy.

3. Today is very hot. I turn on the air conditioner before arriving at home. The comfortable temperature makes me feel relax and happy.

4. I find my kid is listening the story with Xiaoai sound box, which bring happiness to her.

B . 1. Today, I looked at my mobile phone before arriving at home, and I found that the air quality was poor. I bought two pots of green plants, which absorbed carbon dioxide at night, changed the air quality, and made me feel at ease about the health of my family.

2. When I go to work, sometimes I forget to turn off the lights and appliances at home. Almost every day I check them via my mobile phone remotely.

3. Because most of the time I live alone in the apartment, and worry about my security. I always look at the monitor before backing to home. I have feelings of security at that moment.

4. Recently, due to the coming of COVID-19, the family members' body temperatures are measured by XIAOMI thermometer every day. The chart of body temperature changes can be checked by APP every week, which bring relaxation to the health of family members.

Fig. 2. Study process diagram. 
First, due to the household interview, the authors understood the perceptions and expectations of the participants. A semi-structured family interview was conducted the day before the event to gain a general understanding of the use of IoT products.

Second, through the group diary, the users' experiences and perceptions were recorded when they used IoT products. The participants were required to share their thoughts and feelings related to IoT products through social media (we-chat, QQ) at least every two days, and other participants could leave messages and communicate. The purpose was to give the participants the opportunity to think about the functions that they did not expect to use and stimulate feedback from the participants.

Third, through focus groups, the participants shared their past experiences and got more details on the experience based on happy moments.

Fourth, based on videos, family interviews, and social media sharing, the authors used the hierarchical task analysis (HTA) method to create the participants' personal activity table, which provides an objective and typical description of the relevant sub-units of the IoT products based on their activities.

Fifth, according to the subjective statement regarding the source of well-being in the HTA summary table, the two design researchers further sorted out the sub-task column with happiness obtained the positive experience design approaches.

\section{Results Analysis}

At the end of the study, the authors collected the group diaries from social media, including photos, and communication records, and the focus group conversation records. The data was categorized and analyzed using the analytic hierarchy process. Finally, six HTA forms were obtained, which corresponded to the IoT product experience of the six participants. Table 4 shows the HTA table for participant 3 (P3). Based on the HTA and semantic analysis, the authors will introduce the personal IoT product experience results of the six participants.

Table 4. Overview of P3's HTA.

\begin{tabular}{|c|l|l|l|}
\hline $\begin{array}{c}\text { Task } \\
\text { (number of } \\
\text { sub-tasks })\end{array}$ & \multicolumn{1}{|c|}{ Sub-task } & $\begin{array}{l}\text { Sub-task with } \\
\text { well-being }\end{array}$ & \multicolumn{1}{|c|}{ Source of well-being } \\
\hline $\begin{array}{c}\text { Somatosensor } \\
\text { (1) }\end{array}$ & 1.Turn on the light. & $\begin{array}{l}\text { 1. Turn on } \\
\text { the light. }\end{array}$ & $\begin{array}{l}\text { 1. When someone goes to the toilet } \\
\text { at midnight, the light sensor senses } \\
\text { that someone is there and } \\
\text { automatically turns on, which makes } \\
\text { me feel safe and at ease. }\end{array}$ \\
\hline $\begin{array}{c}\text { Wash dishes } \\
\text { (6) }\end{array}$ & $\begin{array}{l}\text { 1. Get the dishwashing } \\
\text { powder; 2. put it in the } \\
\text { bowl; 3. press the power } \\
\text { button; 4. wait; 5. the } \\
\text { mobile phone reminds you } \\
\text { to finish; } 6 . \text { take out the } \\
\text { bowl. }\end{array}$ & $\begin{array}{l}\text { 1. The } \\
\text { mobile phone } \\
\text { reminds you } \\
\text { to finish. }\end{array}$ & $\begin{array}{l}\text { 1. After washing the dishes, the } \\
\text { mobile phone app alerts and displays } \\
\text { the water consumption, time, and so } \\
\text { on, which builds trust in the } \\
\text { machine. }\end{array}$ \\
\cline { 2 - 4 } & $\begin{array}{l}\text { 2. Take out } \\
\text { the bowl. }\end{array}$ & $\begin{array}{l}\text { 2. After sterilization, when taking } \\
\text { out the bowl, it still feels warm, and } \\
\text { there is a sense of happiness that the } \\
\text { health of the family is guaranteed. }\end{array}$ \\
\hline
\end{tabular}




\begin{tabular}{|c|c|c|c|}
\hline \multirow[t]{2}{*}{$\begin{array}{l}\text { Air } \\
\text { purification } \\
\text { (6) }\end{array}$} & \multirow{2}{*}{$\begin{array}{l}\text { 1. Plug in the power; } 2 \text {. } \\
\text { Xiaoai starts the purifier; } \\
\text { 3. select the mode; } 4 \text {. } \\
\text { enjoy the air purification; } \\
\text { 5. check the data on a } \\
\text { mobile phone; } 6 \text {. close the } \\
\text { purifier. }\end{array}$} & $\begin{array}{l}\text { 1. Enjoy the } \\
\text { air } \\
\text { purification. }\end{array}$ & $\begin{array}{l}\text { 1. When the purifier works, you can } \\
\text { find out what the current air quality } \\
\text { is through Xiaoai at any time. }\end{array}$ \\
\hline & & $\begin{array}{l}\text { 2. Check the } \\
\text { data on a } \\
\text { mobile } \\
\text { phone. }\end{array}$ & $\begin{array}{l}\text { 2. The accurate data from the air } \\
\text { purifier reassures me about the } \\
\text { health of my family. }\end{array}$ \\
\hline $\begin{array}{l}\text { Sweep } \\
\text { (4) }\end{array}$ & $\begin{array}{l}\text { 1. Time the sweeping } \\
\text { robot; } 2 \text {. check the } \\
\text { cleaning information on } \\
\text { the mobile phone; 3.be } \\
\text { reminded about } \\
\text { completion; } 4 \text {. automatic } \\
\text { charging. }\end{array}$ & & \\
\hline $\begin{array}{c}\text { Xiaoai } \\
\text { speaker (5) }\end{array}$ & $\begin{array}{l}\text { 1. Wake up; } 2 \text {. choose a } \\
\text { story by voice; } 3 \text {. the } \\
\text { children listen to the story; } \\
\text { 4. the adults listen to } \\
\text { opera; } 5 \text {. the voice stops. }\end{array}$ & $\begin{array}{l}\text { 1. Choose a } \\
\text { story by } \\
\text { voice. }\end{array}$ & $\begin{array}{l}\text { 1._Children choose the story they } \\
\text { want by voice interaction. This } \\
\text { process makes children happy. }\end{array}$ \\
\hline $\begin{array}{l}\text { View } \\
\text { monitoring } \\
\text { (3) }\end{array}$ & $\begin{array}{l}\text { 1. Turn on the mobile } \\
\text { phone; } 2 \text {. view the } \\
\text { monitoring screen; } 3 \text {. turn } \\
\text { off the mobile phone. }\end{array}$ & $\begin{array}{l}\text { 1. View the } \\
\text { monitoring } \\
\text { screen. }\end{array}$ & $\begin{array}{l}\text { 1. When you go to work, you can } \\
\text { check the status of the children and } \\
\text { the elderly at home by voice } \\
\text { interaction, which is reassuring. }\end{array}$ \\
\hline
\end{tabular}

Participant 1's IoT product experience process comprised nine task elements, which were divided into 24 sub-tasks, and the number of sub-tasks that corresponded to each task was different. Among the sub-tasks, six were marked as the sub-tasks that improve happiness, namely a voice interactive alarm clock, Xiaoai music, voice interactive learning to cook, viewing the working screen of the sweeping robot by mobile phone, learning, and reminders about the air quality. For example, when she got up in the morning and used the alarm clock function of the Xiaoai speaker, she found it interesting and pleasant to control the alarm clock by voice. Moreover, she thought that getting up on time would make her feel autonomous, which is an important step to realize her personal goals.

Participant 2 claimed to be a fan of intelligent products and paid close attention to the development of current scientific and technological products. He recorded a total of seven IoT products using various tasks, which were divided into 22 sub-tasks. In the Rubik's cube controller experience task, he summarized the three subtasks as creating a sense of happiness (rotating the Rubik's cube to control lamp brightness, knocking it twice to cause the curtain to open automatically, flipping it to turn off the home appliances automatically). This was recorded as an interactive operation. He thought that it was convenient and interesting to control household products by rotating, shaking, and knocking the Rubik's cube controller. In addition, the participant installed a variety of sensors in his home to form a powerful IoT. Most products had sub-tasks that made him feel happy.

Participant 3 lived with her children and parents, and the study found that most of her sources of happiness were related to her family. She filled in six tasks, which were divided into 25 sub-tasks, of which seven were marked as providing happiness. These were the sensor automatically turning on the light, the dishwasher checking the water consumption data, taking the bowls out of the dishwasher, the purifier working, looking at the purifier feedback data, Xiaoai interactive storytelling, and viewing the monitoring screen on her mobile phone. For 
example, when using the air purifier, she could check the air quality through the mobile app every day. When the air quality index dropped suddenly, it told her the reason why or took recovery measures. If it showed good data, she felt at ease about her family's health. In addition, the storytelling interaction of the Xiaoai speaker with children and family increased the children's interest in learning. Using the mobile phone to check and monitor them when she was at work and checking the status of the elderly at home using voice and video interactions enabled P3 to create a harmonious atmosphere for her family.

During the interview, the authors learned that participant 4's families were concerned about sustainable development and environmental protection. They usually paid attention to the electricity, water quantity, and garbage classification of their homes. Among them were six sources of happiness (mobile phone remote switched off, intelligent lock closed, home automatic power cut-off, Xiaoai reminding them to clean up, voice TV frequency modulation, mobile phone sliding control for light brightness, and the inspection and supervision control screen). For example, when she went to work, she could turn off the lights and air conditioner using her mobile phone if she had forgot to turn them off at home. Additionally, the door lock of the IoT opened automatically, and when she closed the door, the light was automatically turned off. She believed that these functions could not only save family expenses, but also save resources, and provide a sense of social responsibility.

Participants 5 and 6 were both low digital people. In the interview, as they did not know what the IoT was before using IoT products, they had low expectations and trust in the IoT. Their HTA forms showed that the data feedback from IoT products gave them a sense of security. For example, when using the rice cooker, they could use the mobile phone software to check the working process at any time, and when using the air purifier, they could view the air quality data at home. Additionally, after the dishwasher had finished, it would feedback data, such as water consumption and time, to the users. This data feedback promotes product reliability and improves the sense of security and trust of people with a low digital experience level.

The happiness sources of participants 5 and 6 included Xiaoai's "welcome home" voice, an automatic light adjustment mode, family members watching movies together, a desk lamp rotating button to control brightness, pushing the mopping machine button to mop the floor, the remote power failure of mobile phones, and a selection of programs by the Xiaoai speaker. For example, $\mathrm{P} 5$ came home from work every day. After opening the door using the intelligent lock, the Xiaoai speaker automatically played the voice of "welcome home," which made him feel like less lonely. P6 found that compared to the sweeping robot, the use of human-computer interaction made her feel more confident about how clean the house was. It not only easily completes the cleaning, but also takes the exercise, and feels happy.

Based on the above data, the two design researchers further classified the sub-tasks with happiness into four categories according to the source of happiness, which were defined as personal pleasure experience, individual goal realization, group demand satisfaction, and collective relationship harmony (see Fig. 3). 


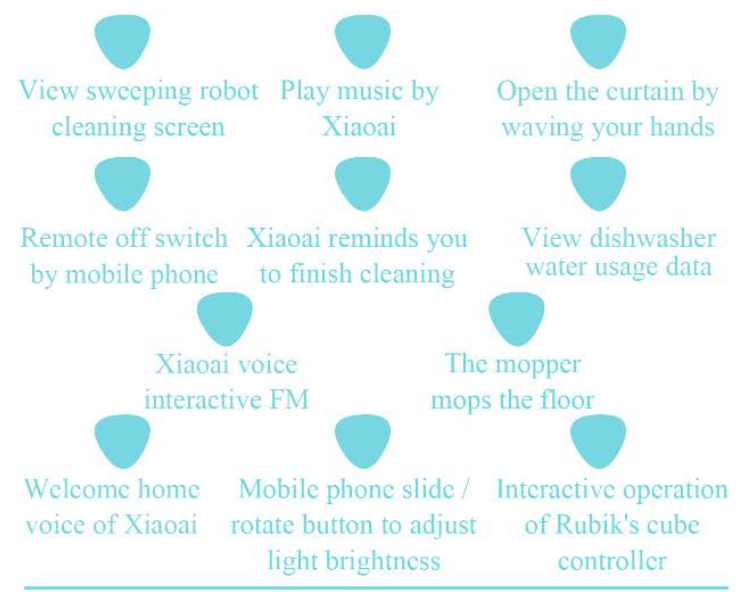

Individual Pleasure Experience

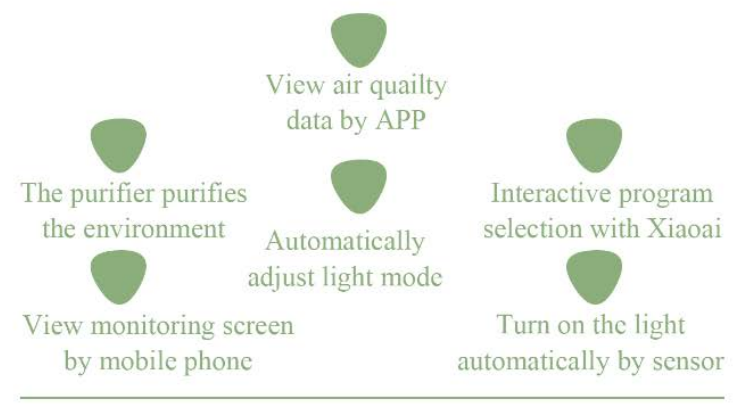

Group Need Satisfaction

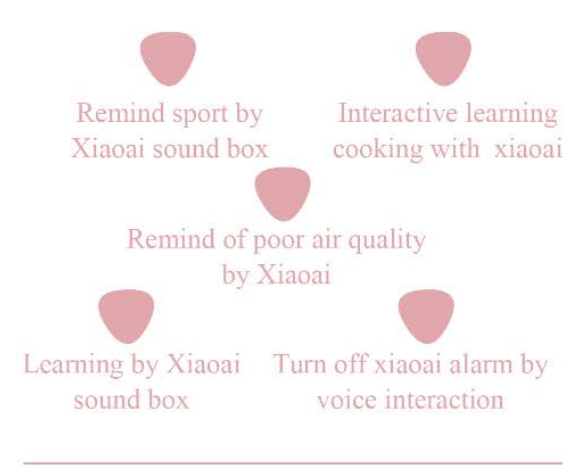

Personal Goal Realization

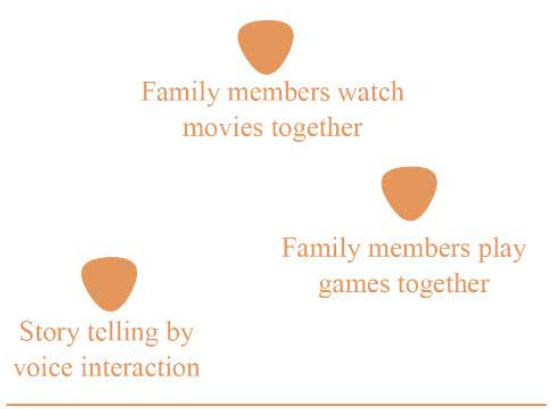

Group Relationship Harmony

Fig. 3. Sub-tasks classification of well-being.

\section{Discussion}

\subsection{General Discussion}

Based on the above research on the user experience of IoT products, combined with previous literature research, the authors further sum up the positive experience design approach of IoT products from two dimensions of the design object (individual, family) and source of happiness (pleasure and meaning). The four design directions are further summarized into the positive experience design approaches of IoT products shown in Fig. 4. The design of IoT products must include both single and multiple individuals with the family as the unit, and there are complex social interactions between individuals. Therefore, designers should pay attention to two design objects (individual and family) in the positive experience design of IoT products. Designers can get inspiration from the following two sources of happiness: pleasure and meaning. Pleasure refers to the short-term satisfaction of needs through happy and comfortable experiences, and meaning refers to the subjective well-being obtained through the purposeful pursuit of self-realization or life value. The details are as follows.

(1) Individual pleasure experience. To achieve the purpose of enjoying a happy experience through positive design, which is when individuals obtain subjective well-being through short-term happiness. The implementation approach can be achieved by either 
improving the disadvantages of existing products, or by strengthening the existing sources of happiness, or introducing new sources of happiness. For example, although the sweeping robot can only sweep the floor to realize the function of sweeping and dragging, the convenience will make people happy. Through the voice control of home products by the Xiaoai speaker, people will find this new interactive way fun. Layous [26] introduced a scientific approach to obtaining happiness in life, and $\mathrm{Wu}$ [27] summarized 15 positive experience design strategies to improve users' subjective well-being.

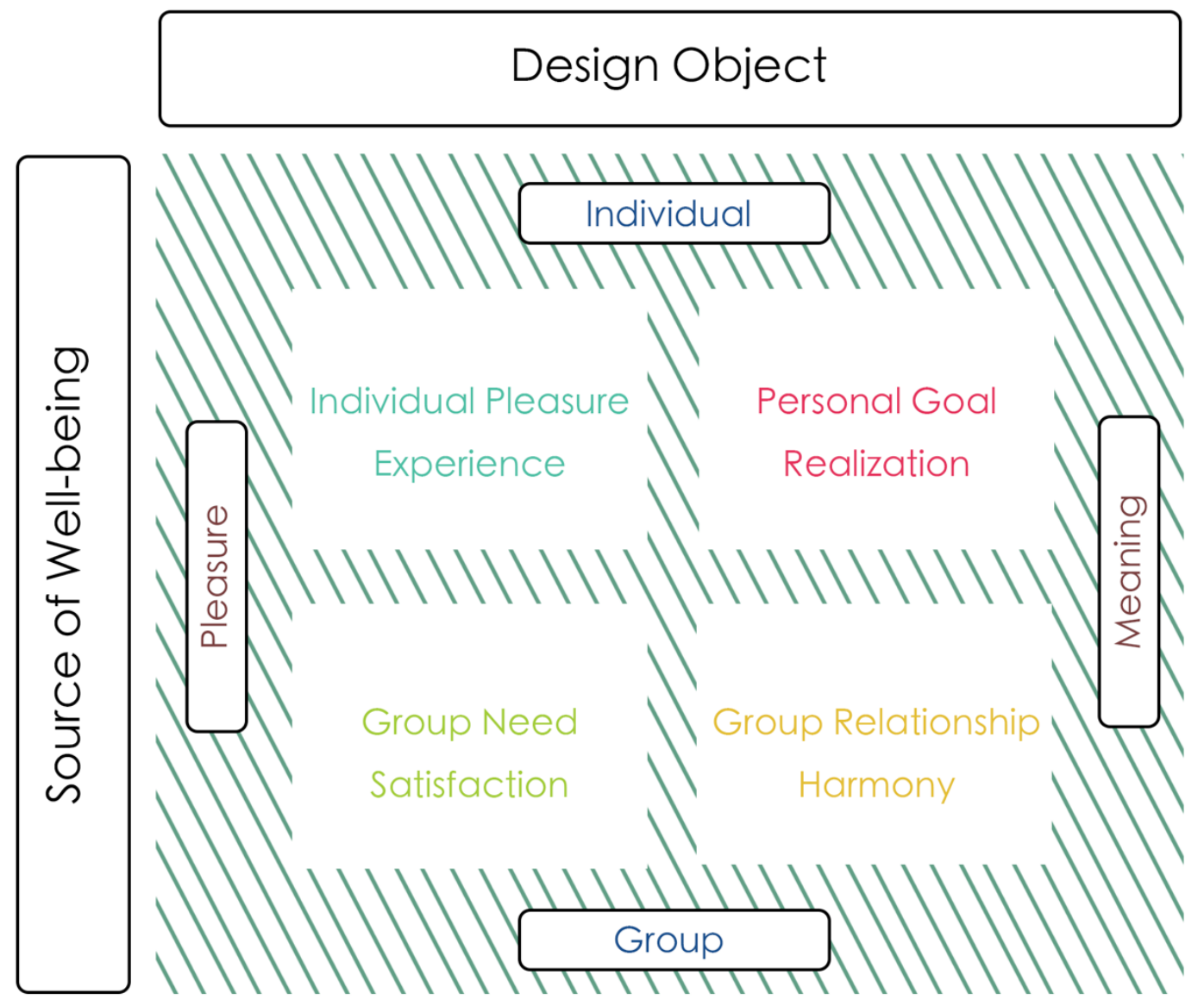

Fig. 4. Positive experience design approaches of IoT products.

(2) Personal goal realization. To obtain subjective well-being through the realization of long-term goals with personal significance. Design is no longer concerned with short-term happiness; it focuses on achieving long-term goals and aspirations. The source of subjective well-being can be the sense of achievement of personal goals, or the sense of progress towards future goals. For example, the interactive voice search for learning materials with the Xiaoai speaker provides a sense of well-being if you achieve excellent results after a certain period of time. Additionally, you will feel happy if you get up and study early due to Xiaoai's alarm clock every day and constantly strive for your own learning goals. Ozkaramanli [28] created a design method, which was named the dilemma-driven design. This method focuses on how to encourage the user to pursue the realization of the long-term goal when the short-term desire 
of the user conflicts with the long-term goal. This design method is also applicable to this section.

(3) Group needs satisfaction. Based on the current situation that the design object of IoT for a family is for multiple individuals, the design should pay more attention to the significance of groups. Tsai et al. [29] proposed that the future IoT product design should be a balance between family members' conflicting and personal values. The positive experience design of IoT products should be designed to meet the experience needs of all family members to achieve subjective well-being. For example, in the family of P3, the Xiaoai speaker became a popular product. She usually used it to control the intelligent products at home, while her mother used it to listen to operas. She often listened to stories with her children, which resulted in some interesting dialogues and interactions. Xiaoai meets the different experience needs of the whole family members.

(4) Harmonious group relationship. Creating a good family atmosphere through positive experience design in the form of through an IoT product results in positive communication between family members, promotes the harmony of family members, and obtains subjective well-being. For example, in this study, P5 and P6 often watched movies with their family members on their home TV, which encouraged everyone to discuss what they had watched. This turned it into a platform carrier to building a harmonious group relationship. In Hassenzahl's [30] research, they found that meaningful moments of happiness can be increased by creating common interests and prolonging the process of experience.

Each of the above directions can affect the positive experience design results of IoT products and stimulate the generation of the subjective well-being of users. However, positive experience design is not only limited to the realization of design objectives in one direction, but can also meet multiple directions at the same time. For example, the learning function of the Xiaoai speaker not only gives users a pleasant experience but also achieves personal goals. Designers can select the design approaches according to different design situations, which helps to inspire IoT product designers to bring users continuous pleasure and enhance their subjective well-being.

\subsection{Design Implications}

To further verify how to apply the positive experience design path of IoT products to the product innovation and design stages, the authors focused on an urban, white-collar couple as the target users, used their weekend afternoon tea as the design scenario, carried out the conceptual design, and generated the following two IoT intelligent products: an interactive kettle and harmonious chair.

Interactive kettle (see Fig. 5): This is an IoT intelligent kettle that can meet the individual's drinking experience and improve the couple's relationship. The innovation is explained from the following four aspects: a) individual pleasure experience: the kettle can sense the user's daily mood changes, accurately output different drinks through the big data calculation, and stimulate the user's positive mood. This design improves the user's positive experience from emotion and taste; b) personal goal realization: the kettle is connected to the computer. When it is time for afternoon tea on the weekend, the computer mouse will transform into a drinking cup shape to remind users that a cup of warm afternoon tea is ready. By reminding users to drink tea and enjoy life, the goal of personal health can be achieved; c) group need satisfaction: the kettle has two water cups, which meet the needs of two people for different drinks at the same time (for example, the man likes to drink coffee and the woman likes to drink tea). This meets the group's needs; d) group relationship harmony: the display 
screen of the kettle immediately reminds both parties of the latest drinking water data indicators. Through a visual comparison, they can each drink water and actively prepare drinks for each other, which achieves the goal of a group harmonious relationship.
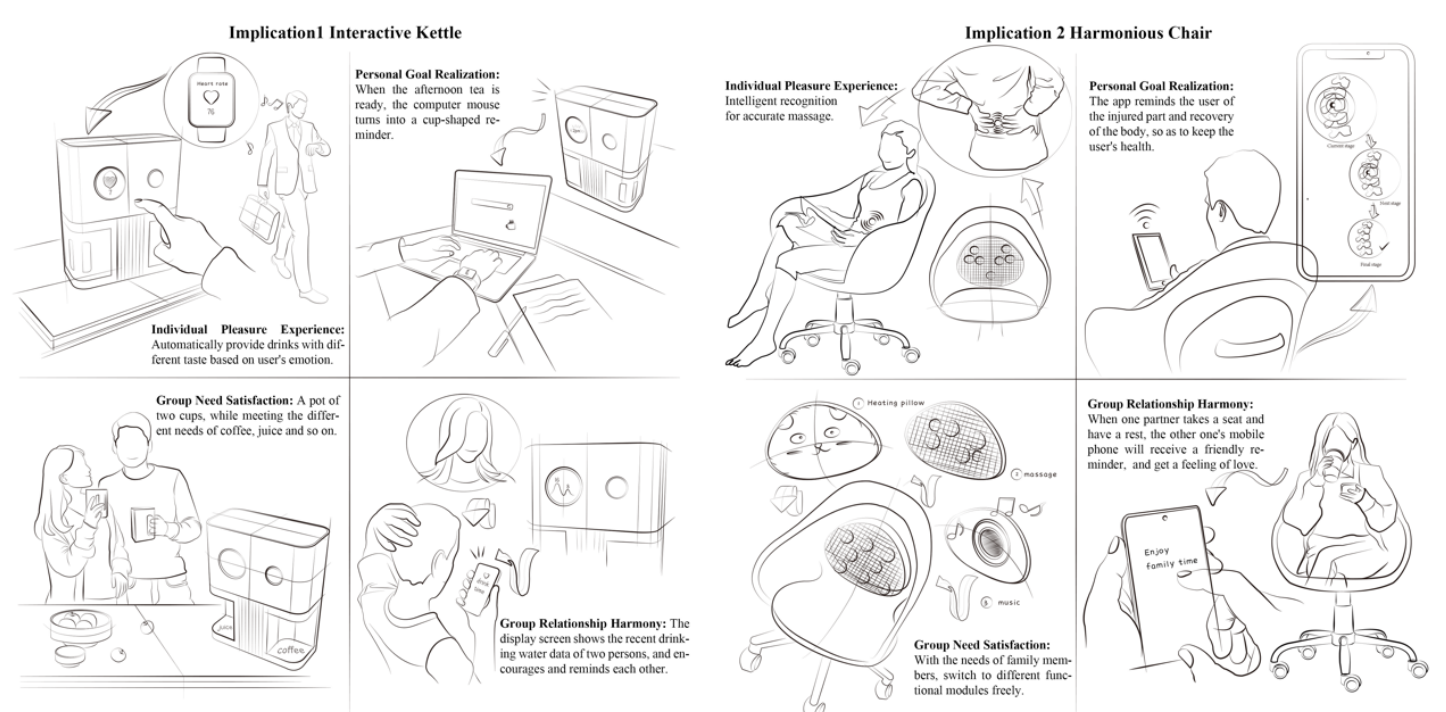

Fig. 5. Design implications.

Harmonious chair (see Fig. 5): This is an IoT chair that not only meets the individual's leisure massage experience but also enhances sharing between the couple. It is a positive experience, and the innovations are as follows: a) individual pleasure experience: it has an intelligent recognition and massage module. When the user is seated, the module can identify the user's areas of lumbar muscle strain, carry out the appropriate massage, and improve the user's experience; b) personal goal realization: when the user is having a leisure massage, the app matches the seat and reminds the user of the injured area and recovery treatment to improve the user's health; c) group need satisfaction: the massage module can switch to different functional modules according to the needs of the family members, such as a music playing module or air purification module. By switching between different modules, the purpose of meeting the group's needs can be achieved; d) group relationship harmony: when one of the couples sits down for leisure, their partner's mobile phone will give a friendly reminder to cherish the leisure time, and feel the other's concern, which will promote a harmonious relationship between the couple.

\section{Conclusion}

In the era of artificial intelligence and IoT, improving the subjective well-being of individuals and groups, and dealing with the conflict arising from the needs of groups is becoming increasingly important.

This paper has two contributions. At the theoretical level, based on the relevant theory of positive experience design, through the two-week study on the use of IoT products by the users, this paper proposes a positive experience design approach of IoT products to improve the subjective well-being of users, including the following four IoT product design directions: individual pleasure experience, personal goal realization, group need satisfaction, and group 
relationship harmony. At the practical design level, based on this design method, the authors proposed the following two IoT product concepts that were driven by positive experience: the interactive kettle and harmonious chair. Through the design illustration of these two products, the feasibility of the design approach has been further verified.

The limitations of the research are as follows: due to the differences in the number of participants, and their knowledge and experience, the output of the final approach may be affected. This paper only verifies the positive experience design approach during the early concept stage. On the basis of the research method, subsequent designers should carry out more IoT product design practices to verify the feasibility and effectiveness of the design approach, and contribute the relevant positive experience design knowledge.

\section{References}

[1] M. Cho, S. Lee, and K. P. Lee, "How do people adapt to use of an IoT air purifier?: From low Expectation to Minimal Use,” Int. J. Des., vol. 13, no. 3, pp. 21-38, 2019. Article (CrossRef Link)

[2] J. Yoon, A. E. Pohlmeyer, P. M. A. Desmet, and C. Kim, "Designing for positive emotions: issues and emerging research directions,” The Design Journal, vol. 14, no. 2, pp. 167-187, Nov. 2020. Article (CrossRef Link)

[3] P. M.A. Desmet, and A. E. Pohlmeyer, "Positive design: an introduction to design for subjective well-Being,” Int. J. Des., vol 7, no. 3, pp. 5-19, 2013. Article (CrossRef Link)

[4] D. Sayar and O. Er, "The antecedents of successful IoT service and system design: cases from the manufacturing industry,” Int. J. Des., vol 12, no. 1, pp. 67-78, 2018. Article (CrossRef Link)

[5] M. Ghajargar, M. Wiberg, and E. Stolterman, "Designing IoT systems that support reflective thinking: a relational approach,” Int. J. Des., vol. 12, no. 1, pp. 21-35, 2018.

Article (CrossRef Link)

[6] J. C. Jae and J. K. Hyun, "An automobile environment detection system based on deep neural network and its implementation using IoT-enabled in-vehicle air quality sensors," Sustainability, vol. 12, no. 6, pp. 2475-2492, 2020.Article (CrossRef Link)

[7] S. Feng, P. Setoodeh, and S. Haykin, "Smart home: cognitive interactive people-centric internet of things,” IEEE Commun. Mag., vol. 55, no. 2, pp. 34-39, 2017. Article (CrossRef Link)

[8] A. D. Dwivedi, G. Srivastava, S. Dhar, and R. Singh, "A decentralized privacy-preserving healthcare blockchain for IoT,” Sensors, vol. 19, no. 2, pp. 326-343, 2019.Article (CrossRef Link)

[9] N. Fairman, A. Martin, and P. Knapp, "Flourishing: positive psychology and the life well-lived," $J$. Am. Acad. Child Psy., vol. 44, no. 8, pp. 834-835, 2005. Article (CrossRef Link)

[10] S. L. Gable and J. Haidt, "What (and why) is. positive psychology?,” Rev. Gen. Psychol., vol. 9, no. 2, pp. 103-110, 2005. Article (CrossRef Link)

[11] C. Wu, W. Wei and P. Li, "Positive design model for improving subjective well-being," Packaging Engineering, vol. 40, no. 12, pp. 29-33, 2019. Article (CrossRef Link)

[12] M. Hassenzahl, K. Eckoldt, S. Diefenbach, M. Laschke, E. Lenz, and, J. Kim, "Designing moments of meaning and pleasure: experience design and happiness," Int. J. Des., vol 7, no. 3, pp. 21-31, 2013. Article (CrossRef Link)

[13] C. M. Wu, X. N. Zhang, and X. Wu, "Construction of conceptual design canvas based on positive experience,” Packaging Engineering, vol. 41, no. 16, pp. 76-82, 2020. Article (CrossRef Link)

[14] D. Orth, C. Thurgood, and E. Hoven, "Designing objects with meaningful associations," Int. J. Des., vol. 12, no. 2, pp. 91-104, 2018. Article (CrossRef Link)

[15] M. Casais, R. Mugge, and P. Desmet, "Objects with symbolic meaning: 16 directions to inspire design for well-being,” J. Des. Res., vol. 16, no. 3/4, pp. 247-281, 2018. Article (CrossRef Link)

[16] L. Wiese, A. Pohlmeyer, and P. Hekkert, "Activities as a gateway to sustained subjective wellbeing mediated by products," in Proc. of the 2019 on Designing Interactive Systems Conference, pp. 85-97, 2019. Article (CrossRef Link) 
[17] D. Ozkaramanli, E. Ozcan, and P. M. A. Desmet, "Long-term goals or immediate desires? introducing a toolset for designing with self-control dilemmas,” The Design Journal, vol. 20, no. 2, pp.219-238, 2017. Article (CrossRef Link)

[18] S. Maria, K. Hellen, and P. M. A. Desmet, "The "you and I" of happiness: investigating the longterm impact of self- and other- focused happiness-enhancing activities,” Psychol. Market., vol. 34, no. 6, pp. 623-630, 2017. Article (CrossRef Link)

[19] J. K. Yoon, A. E. Pohlmeyer, and P. M. A. Desmet, "When 'feeling good' is not good enough: seven key opportunities for emotional granularity in product development,” Int. J. Des., vol. 10, no. 3, pp. 1-15, 2016. Article (CrossRef Link)

[20] P. M. A. Desmet, H. Xue, and S. Fokkinga, "The same person is never the same: introducing moodstimulated thought/action tendencies for user-centered design,” She Ji, vol.5, no. 3, pp. 167-187, 2019. Article (CrossRef Link)

[21] C. M. Wu, X. N. Zhang, and X. Wu, "Construction of conceptual design canvas based on positive experience,” Packaging Engineering, vol. 41, no. 16, pp. 76-82, 2020. Article (CrossRef Link)

[22] P. M. A. Desmet, and S. Fokkinga, "Beyond maslow’s pyramid: introducing a typology of thirteen fundamental needs for human-centered design,” Multimodal Technol. Interact., vol. 4, no. 3, pp. 1-22, Jul. 2020.Article (CrossRef Link)

[23] S. Jimenez, A. E. Pohlmeyer, and P. M. A. Desmet, "Positive design reference guide," Delft, Netherland, 2015.Article(Web link)

[24] P. Patel, and D. Cassou, "Enabling high-level application development for the internet of things," J. Syst. Software, vol. 103, pp. 62-84, 2015. Article (CrossRef Link)

[25] P. Li, and Z. Y. Liu, “E-customized product: user-centered co-design experiences,” KSII T. Internet Inf., vol. 14, no. 9, pp. 3680-3692, Sep. 2020. Article (CrossRef Link)

[26] K. Layous, J. Kurtz, J. Chancellor, and S. Lyubomirsky, "Reframing the ordinary: imagining time as scarce increases well-being," J. Posit. Psychol., vol.13, no.3, pp. 301-308, Jan. 2017. Article (CrossRef Link)

[27] C. M. Wu, and X. M. Tian, "Positive Experience Design Strategies to Improve Subjective Wellbeing,” Packaging Engineering, 2020. Article (CrossRef Link)

[28] D. Ozkaramanli, "Me against myself: addressing personal dilemmas through design,” Ph.D. dissertation, Dept. Indus. Des. Eng., Delft Univ. of Technology, Netherland, 2017. Article (Web link)

[29] W. C. Tsai, Y. L. Chuang, and L. L. Chen, "Balancing between conflicting values for designing subjective well-being for the digital home,” in Proc. of APCHIUX, pp. 33-36, 2015. Article (CrossRef Link)

[30] H. Klapperich, A. Uhde, and M. Hassenzahl, "Designing everyday automation with well-being in mind," Pers. Ubiquit. Comput., vol.24, pp. 763-779, Dec. 2020.Article (CrossRef Link) 


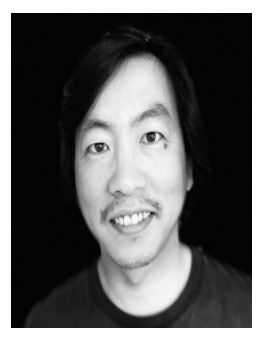

Chunmao Wu: He received the Ph.D. degree in Industrial Design from Kyonggi University, Republic of Korea. Now he is an Associate Professor in the Department of Product Design, College of Fashion and Design, Donghua University, Shanghai, China. His research interests include the positive experience design, product service system design, future interaction design, and other related areas.

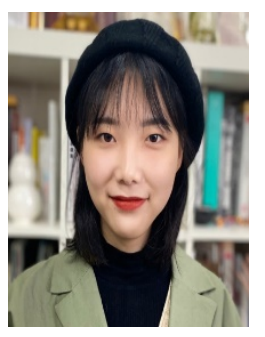

Huayuan Xu: She received the B.S. degree in Product Design from North China Electric Power University, Hebei, China, in 2019. She is currently working toward the M.S. degree in design studies at the Donghua University, Shanghai, China. Her research interests focus on positive experience design and IoT product design.

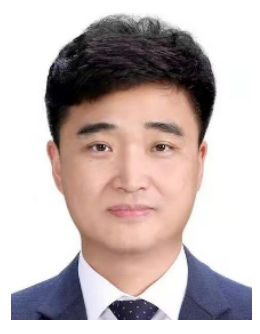

Ziyang Liu: He received the B.A. degree in Management from the Institute of Army Staff Officer of the PLA, China, in 2006, M.A. degree and Ph.D. degree in Management from Kyonggi University, Korea, in 2010 and 2013, respectively. He is currently an Assistant Professor in the Global Business College, Kyonggi University. He is interested in quality management, management information systems, international economics, E-customization etc. 